\title{
CRYSTALLIZATION DURING VOLUME REDUCTION OF SOLUTIONS WITHA COMPOSITION CORRESPONDING TO THAT IN THE COLLECTING DUCT. THE INFLUENCE OF HYDROXYAPATITE SEED CRYSTALS AND URINARY MACROMOLECULES
}

\author{
Inge Højgaard, Anne-Marie Fornander, Mari-Anne Nilsson and Hans Göran Tiselius* \\ Department of Urology and the Clinical Research Center, \\ Faculty of Health Sciences, University Hospital, S-58185 Linköping, Sweden
}

(Received for publication December 29, 1996 and in revised form May 11, 1997)

\begin{abstract}
To examine the effect of hydroxyapatite (HAP) seed crystals and urinary macromolecules on the crystallization under conditions similar to those in the collecting duct (CD), we evaporated $100 \mathrm{ml}$ samples of salt solutions with an ioncomposition assumed to correspond to that in the CD without and with HAP seed crystals. The crystallization in seeded solutions was assessed both with and without dialyzed urine $(\mathrm{dU})$. After evaporation, the number and volume of crystals were recorded and the crystal morphology was examined with scanning electron microscopy (SEM) and X-ray crystallography.

Addition of HAP crystals was apparently followed by an approximately $15-20 \%$ increase in heterogeneous nucleation of calcium oxalate $(\mathrm{CaOx})$. In these experiments, SEM and X-ray crystallography showed a high percentage of $\mathrm{CaOx}$ in the precipitate.

In samples reduced to $40-69 \mathrm{ml}$, addition of $\mathrm{dU}$ to the CD solution containing HAP seed resulted in a greater mean (SD) number of crystals: 3895(1841) in samples with dU and 1785(583) in samples without. This was mainly explained by an increased mean (SD) number of small crystals. The mean crystal volume was 17.8(1.1) and 34.3(9.1) in samples reduced to $40-69 \mathrm{ml}$ with and without $\mathrm{dU}$, respectively. This might reflect the inhibitory effect of dU on the growth and/ or aggregation of the $\mathrm{CaOx}-\mathrm{CaP}$ precipitate or a promoted nucleation resulting in a great number of small crystals.

It is concluded that calcium phosphate $(\mathrm{CaP})$ formed above the collecting duct might induce heterogeneous nucleation of $\mathrm{CaOx}$ at lower levels of the renal collecting system, and that urinary macromolecules are powerful modifiers of these processes.
\end{abstract}

Key Words: Crystallization, hydroxyapatite, calcium phosphate, calcium oxalate, collecting duct, macromolecules, promotion, inhibition.

*Address for correspondence:

H.G. Tiselius, address as above

FAX no.: 46858587760

E-mail:Hans-Goran.Tiselius@uro.hs.sll.se

\section{Introduction}

The mechanisms of formation of urinary calcium oxalate containing concrements are incompletely understood, and the process can certainly not be explained only by a crystallization of calcium oxalate $(\mathrm{CaOx})$. Urinary stones have an organic matrix accounting for approximately $2.5 \%$ of the weight of the stone (Boyce, 1956). It has also been shown that a considerable fraction of $\mathrm{CaOx}$ stones is composed of mixtures of $\mathrm{CaOx}$ and calcium phosphate (CaP) (Prien, 1955; Pak et al., 1971, Peacock et al., 1979; Larsson et al., 1984a, b; Ohkawa et al., 1992; Tiselius, 1996). Furthermore, Leusmann et al. (1984) showed that more than $70 \%$ of oxalate rich stones had $\mathrm{CaP}$ within or near the central core of the stone.

It is reasonable to assume that the crystallization is initiated in the nephron (Coe and Parks, 1990; DeGanello et al., 1990; Lupták et al., 1994; Kok, 1995; Asplin et al., 1996; Højgaard et al., 1996, 1997; Tiselius et al., 1997). Finlayson and Reid (1978) showed that even with a maximal crystal growth of $\mathrm{CaOx}$ the renal transit time was too short to result in crystals with a size that would obstruct the collecting duct. Baumann et al. (1984) showed that after an oral oxalate load, the size of the crystals was generally smaller than 200 $\mu \mathrm{m}$ in a concentrated overnight urine. In a recent experimental study, Kok and Khan (1994), however, concluded that during the normal transit time for urine through the nephron, crystalline particles might form large enough to be retained, mainly due to the size-increasing effect of agglomeration. Thus, a pronounced agglomeration and crystal retention are factors that might be of importance for stone development. Randall's plaques seem to start from a CaP deposition in the papillary tissue (Prien, 1975) and it has been shown that crystals of hydroxyapatite (HAP) can induce a heterogeneous crystallization of $\mathrm{CaOx}$ (Smith and Werness, 1983; Baumann et al., 1989; Berg and Tiselius, 1989; Hallson and Rose, 1989; Grases and Conte, 1992). Crystals of CaP that are retained in the nephron or in the renal collecting system are, therefore, highly interesting as possible promoters of $\mathrm{CaOx}$ nucleation.

In two recent works (Lupták et al., 1994; Højgaard et 
al., 1996), we have shown that there is a risk of CaP crystal formation in the proximal and distal tubule, whereas, $\mathrm{CaOx}$ is the primary type of crystal that forms in the collecting duct. In a recent study, Kok (1995) also found that crystallization of $\mathrm{CaOx}$ is most likely in the collecting duct, and it has been shown by several authors that there is a high risk of $\mathrm{CaP}$ crystallization at a nephron level above the collecting duct (Coe and Parks, 1990; Kok, 1995; Asplin et al., 1996). These observations have raised the question on whether $\mathrm{CaP}$ formed at a high level in the nephron is a natural and common promoter of $\mathrm{CaOx}$ nucleation in the collecting duct. A heterogeneous crystallization of $\mathrm{CaOx}$ induced by $\mathrm{CaP}$ is a mechanism that previously has been proposed by several authors (Meyer et al., 1975, 1977; Pak et al., 1976; Koutskoukos and Nancollas, 1981; Pak, 1981; Baumann, 1985; Berg and Tiselius, 1989; Achilles et al., 1994; Hufnagel et al., 1995).

The aim of this study was to examine if CaP crystals can induce a heterogeneous nucleation of $\mathrm{CaOx}$ under conditions corresponding to those in the collecting duct and to study the possible influence of the urinary macromolecules on this process. Since HAP is thermodynamically the most stable form of $\mathrm{CaP}$ (Christoffersen $e t$ al., 1990), HAP crystals were used in these experiments.

\section{Materials and Methods}

Salt solutions with an ion-composition assumed to correspond to that of urine in the distal part of the collecting duct were prepared by dissolving the following commercially available salts: calcium chloride $\left(\mathrm{CaCl}_{2} \cdot 2 \mathrm{H}_{2} \mathrm{O}\right)$, magnesium chloride $\left(\mathrm{MgCl}_{2} \cdot 6 \mathrm{H}_{2} \mathrm{O}\right)$, sodium chloride $(\mathrm{NaCl})$, potassium chloride $(\mathrm{KCl})$, sodium sulphate $\left(\mathrm{Na}_{2} \mathrm{SO}_{4}\right)$, sodium phosphate $\left(\mathrm{Na}_{2} \mathrm{HPO}_{4}\right)$, sodium oxalate $\left(\mathrm{C}_{2} \mathrm{Na}_{2} \mathrm{O}_{4}\right)$ and sodium citrate $\left(\mathrm{C}_{6} \mathrm{H}_{5} \mathrm{Na}_{3} \mathrm{O}_{7} \cdot 2 \mathrm{H}_{2} \mathrm{O}\right)$ in Millipore (Millipore S.A., Molsheim, France) filtered water as previously described (Lupták et al., 1994). One liter of this solution was given the following ion-composition: calcium $4.50 \mathrm{mmol}$, magnesium $3.85 \mathrm{mmol}$, phosphate $32.3 \mathrm{mmol}$, oxalate 0.32 mmol, citrate $3.21 \mathrm{mmol}$, sodium $106 \mathrm{mmol}$, potassium 63.7 mmol, and sulphate $20.8 \mathrm{mmol}$. No ammonium was added to avoid the risk of precipitating ammonium salts. The $\mathrm{pH}$ was set to 5.80 which was considered the average $\mathrm{pH}$ in the collecting duct according to the results reported by Rector (1983).

A suspension of hydroxyapatite (HAP) seed crystals with a concentration of $400 \mu \mathrm{g} / \mathrm{ml}$ was prepared by adding the commercially available salt (Merck AG, Darmstadt, Germany) to Millipore filtered water. After ultrasonication for 30 minutes, the crystal size distribution was analysed in the Coulter Multisizer (Coulter Electronic Ltd., Luton, U.K.). No crystals were found with a size greater than $15.4 \mu \mathrm{m}$ and the size distribution showed that $93 \%$ of the crystals had a

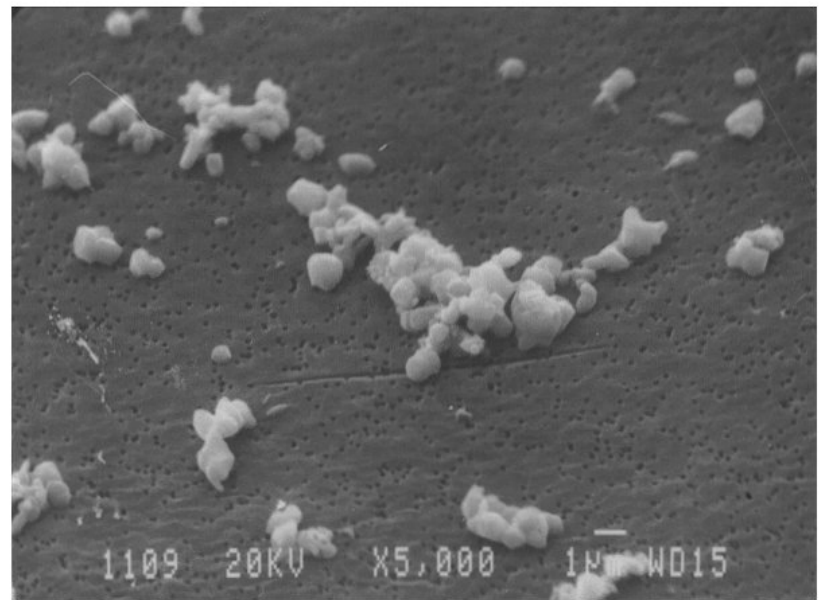

Figure 1. Scanning electron micrograph of HAP seed crystals at a concentration of $400 \mu \mathrm{g} / \mathrm{ml}$. Bar $=1 \mu \mathrm{m}$.

diameter of 2.4 to $4.4 \mu \mathrm{m}, 5 \% 4.5$ to $5.4 \mu \mathrm{m}$, and $2 \% 5.5$ to 15.4 $\mu \mathrm{m}$. Scanning electron microscopy of suspensions showed that a major part of the crystals were smaller than $2.4 \mu \mathrm{m}$ and that the fractions found in different size intervals were composed of HAP crystal aggregates (Fig. 1).

Pooled dialyzed bladder urine $(\mathrm{dU})$ from 10 normal male subjects was used as a source of macromolecules, thereby, ignoring the fact that certain macromolecules might have been added to the urine as a result of its passage and storage in the lower parts of the urinary system, whereas, others might have been removed during the preparation of dU. This urine was collected between 2200 and 0600 hours, and screened to exclude bacteria, protein and glucose before being pooled. Urine was dialyzed as previously described (Lupták et al., 1994). According to the concentration of urine in the distal part of the collecting duct, the samples with $\mathrm{dU}$ were prepared by dissolving the necessary salts in the $\mathrm{dU}$.

Solution samples of $100 \mathrm{ml}$ were passed through 0.22 $\mu \mathrm{m}$ pore size Millipore filters before evaporation in a Büchi Rotavapor RE (Büchi AG, Flawil, Switzerland) at $37^{\circ} \mathrm{C}$. The filtration was carried out at room temperature at a rate of approximately $1 \mathrm{ml} / \mathrm{sec}$. Evaporation was performed of salt solutions without both HAP and dU (CD-solution), of salt solutions with $1 \mathrm{ml}$ of HAP suspension but without $\mathrm{dU}$ (CD-HAP-solution), and of salt solutions with $1 \mathrm{ml}$ of HAP suspension and with dU (CD-HAPdU-solution). After evaporation to a predetermined volume, the number and volume of crystals in the size interval 2.4 to $45 \mu \mathrm{m}$ were recorded in a Coulter Multisizer with a $100 \mu \mathrm{m}$ capillary tube which we have found most appropriate for assessing crystals in this interval. Furthermore, the distribution of the crystals was recorded in the following size interval: 2.4 to $5.1 \mu \mathrm{m}, 5.1$ 
Table 1. The percentage of different calcium salts in the precipitate at different degrees of evaporation of $100 \mathrm{ml}$ samples of CD, CD-HAP and CD-HAPdU-solutions analysed by X-ray crystallography.

\begin{tabular}{|c|c|c|c|c|c|c|c|c|}
\hline \multirow[b]{2}{*}{$\begin{array}{l}\text { Sample volume } \\
\text { after evaporation }\end{array}$} & \multirow[b]{2}{*}{$\begin{array}{c}\text { Salt } \\
\text { solution }\end{array}$} & & \multicolumn{6}{|c|}{ Per cent of calcium salt in the sample } \\
\hline & & & COD & $\mathrm{COM}$ & Bru & HAP & $\begin{array}{l}\text { total } \\
\mathrm{CaOx}\end{array}$ & $\begin{array}{l}\text { total } \\
\mathrm{CaP}\end{array}$ \\
\hline \multirow{6}{*}{$70-80 \mathrm{ml}$} & $\mathrm{CD}$ & $0 \mathrm{~min}$ & 50 & $\mathbf{0}$ & 40 & 10 & 50 & 50 \\
\hline & & $60 \mathrm{~min}$ & 35 & 0 & 55 & 10 & 35 & 65 \\
\hline & HAP & $0 \mathrm{~min}$ & 45 & 20 & 5 & 30 & 65 & 35 \\
\hline & & $60 \mathrm{~min}$ & 15 & 45 & 5 & 35 & 60 & 40 \\
\hline & HAP-CDdU & $0 \mathrm{~min}$ & 35 & $\mathbf{0}$ & 5 & 60 & 35 & 65 \\
\hline & & $60 \mathrm{~min}$ & 20 & 0 & 5 & 75 & 20 & 80 \\
\hline \multirow{6}{*}{$40-50 \mathrm{ml}$} & $\mathrm{CD}$ & 0 min & 35 & $\mathbf{0}$ & 60 & 5 & 35 & 65 \\
\hline & & $60 \mathrm{~min}$ & 20 & 0 & 65 & 15 & 20 & 80 \\
\hline & HAP & $0 \mathrm{~min}$ & 50 & 5 & 10 & 35 & 55 & 45 \\
\hline & & $60 \mathrm{~min}$ & 40 & 0 & 50 & 10 & 40 & 60 \\
\hline & HAP-CDdU & $0 \mathrm{~min}$ & 60 & $\mathbf{0}$ & 5 & 35 & 60 & 40 \\
\hline & & $60 \mathrm{~min}$ & 35 & 0 & 5 & 60 & 35 & 65 \\
\hline \multirow{6}{*}{$10-20 \mathrm{ml}$} & $\mathrm{CD}$ & $0 \mathrm{~min}$ & 10 & $\mathbf{0}$ & 70 & 20 & 10 & 90 \\
\hline & & $60 \mathrm{~min}$ & 5 & 0 & 90 & 5 & 5 & 95 \\
\hline & HAP & $0 \mathrm{~min}$ & 30 & $\mathbf{0}$ & 40 & 30 & 30 & 70 \\
\hline & & $60 \mathrm{~min}$ & 20 & 0 & 70 & 10 & 20 & 80 \\
\hline & HAP-CDdU & $0 \mathrm{~min}$ & 20 & $\mathbf{0}$ & 75 & 5 & 20 & 80 \\
\hline & & $60 \mathrm{~min}$ & 5 & 5 & 85 & 5 & 10 & 90 \\
\hline
\end{tabular}

to $10.2 \mu \mathrm{m}, 10.2$ to $20.2 \mu \mathrm{m}$ and 20.2 to $45 \mu \mathrm{m}$. Recordings were carried out both immediately after evaporation and after 60 minutes of continuous agitation in an incubator at $37^{\circ} \mathrm{C}$. The mean crystal volume (MCV) was calculated as the ratio between the total volume $\left(\mu \mathrm{m}^{3}\right)$ and the total number of crystals. After evaporation, the mean and standard deviation (SD) were calculated for the following sample volume intervals: 70 to $95 \mathrm{ml}$ (Sample A), 40 to $69 \mathrm{ml}$ (Sample B), and 10 to $39 \mathrm{ml}$. No sample volume was reduced to more than $10 \%$ of its original volume.

The ion-activity products of $\mathrm{CaOx}\left(\mathrm{AP}_{\mathrm{CaOx}}\right)$, calcium hydrogen phosphate, brushite $\left(\mathrm{AP}_{\mathrm{Bru}}\right)$, hydroxyapatite $\left(\mathrm{AP}_{\mathrm{HAP}}\right)$, amorphous calcium phosphate $\left(\mathrm{AP}_{\mathrm{ACP}}\right)$, and octacalcium phosphate $\left(\mathrm{AP}_{\mathrm{OCP}}\right)$ at different degrees of evaporation, were calculated by means of computerized iterative approximation with the EQUIL2 program (Werness et al., 1985). For ACP, we used the approximate formula $\mathrm{Ca}\left(\mathrm{PO}_{4}\right)_{0.74}(\mathrm{H})_{0.22}$ (Christoffersen et al., 1990).

The crystal morphology was studied in a JEOL JSM840 scanning electron microscope (JEOLLtd., Tokyo, Japan). Preparation for scanning electron microscopy (SEM) was performed as described in detail previously (Lupták et al., 1994).

Solutions CD, CD-HAP and CD-HAPdU were evap- orated down to a volume of 70-80 ml, 40-50 $\mathrm{ml}$ and 10-20 ml. Half of the crystalline material recovered from these samples was pooled before being centrifuged at $1500 \mathrm{rpm}$ for 15 minutes. The other half was left for 60 minutes of continuous agitation in an incubator at $37^{\circ} \mathrm{C}$ before being pooled and centrifuged at $1500 \mathrm{rpm}$ for 15 minutes. The sediment was dried in air and then subjected to X-ray crystallographic examination at L.C. Herring and Company (Orlando, FL, USA) to quantitatively assess the content of $\mathrm{CaOx}$ and $\mathrm{CaP}$. Statistical analysis

Wilcoxon's rank sum test (Swinscow, 1976) was used for comparing samples with and without HAP, and with and without dU. Wilcoxon's signed rank test was used to compare samples immediately after evaporation with those obtained after 60 minutes of continuous agitation in the incubator.

\section{Results}

Scanning electron microscopy showed that volume reduction of the $\mathrm{CD}$-solution resulted in formation of $\mathrm{CaOx}$ and $\mathrm{CaP}$ crystals. $\mathrm{CaOx}$ dihydrate (COD) was the predominant crystal phase in the least concentrated samples immediately after the evaporation (Fig. 2A), whereas, CaP 
Table 2. Mean (SD) number, total crystal volume and mean crystal volume (MCV) at different sample volumes immediately and 60 minutes after evaporation of $100 \mathrm{ml}$ samples of CD, CD-HAP and CD-HAPdU-solutions.

\begin{tabular}{|c|c|c|c|c|c|c|}
\hline \multirow{2}{*}{\multicolumn{2}{|c|}{$\begin{array}{l}\text { Crystal size } \\
2.4 \text { to } 45 \mu \mathrm{m} . \quad \text { CD }\end{array}$}} & \multicolumn{2}{|c|}{ Sample A $(70-95 \mathrm{ml})$} & \multicolumn{3}{|c|}{ Sample B (40-69 ml) } \\
\hline & & CD-HAP & CD-HAPdU & $\mathrm{CD}$ & CD-HAP & CD-HAPdU \\
\hline \multicolumn{7}{|c|}{ The number of crystals } \\
\hline $0 \min$ & $131(133) \dagger \dagger$ & $1372(378)^{\circ}$ & $1479(588)$ & $347(315) \dagger^{\circ}$ & $1785(533)^{\circ}$ & $3895(1841)^{* * \circ}$ \\
\hline $60 \mathrm{~min}$ & $127(142)$ & $926(232)^{\circ}$ & $1414(755)$ & $1999(1476) \dagger^{\circ}$ & $2659(1089)^{\circ}$ & $5398(2254)^{\circ}$ \\
\hline \multicolumn{7}{|c|}{ The total crystal volume $\left(1000 \times \mu \mathrm{m}^{3}\right)$} \\
\hline $0 \min$ & $30.4(41.0)$ & $54.3(26.6)$ & $61.6(42.3)$ & $30.2(31.5) \dagger^{\circ}$ & $59.9(19.3)^{\circ}$ & $134(50.9)^{* * \circ}$ \\
\hline $60 \mathrm{~min}$ & $27.0(34.7)$ & $44.7(13.5)$ & $88.5(81.8)$ & $405(508)^{\circ}$ & $396(474)^{\circ}$ & $482(325)^{\circ}$ \\
\hline \multicolumn{7}{|l|}{ MCV } \\
\hline $0 \min$ & $178(133) \dagger$ & $38.9(9.7)$ & $16.7(1.1)^{* * \circ}$ & $101(57.7) \dagger \dagger$ & $34.3(9.1)^{\circ}$ & $17.8(1.1)^{* * \circ}$ \\
\hline $60 \mathrm{~min}$ & $234(120)$ & $49.7(12.9)$ & $55.2(34.2)^{\circ}$ & $164(150)$ & $122(110)^{\circ}$ & $82.3(32.0)^{\circ}$ \\
\hline \multicolumn{7}{|c|}{ number of experiments } \\
\hline & 5 & 5 & 6 & 6 & 8 & 6 \\
\hline
\end{tabular}

Comparison of CD and CD-HAP samples $\dagger \mathrm{p}<0.05$; $\dagger$ p $<0.01$.

Comparison of CD-HAP and CD-HAPdU samples $* \mathrm{p}<0.05$; ** $<<0.01$.

Comparison of samples immediately and 60 minutes after evaporation ${ }^{\circ} \mathrm{p}<0.05$.

became more common in samples subjected to a more excessive volume reduction (Fig. 2E). CaP predominated in samples drawn after 60 minutes irrespective of the degree of volume reduction (Figs. 2B, 2D and 2F). These findings were supported by X-ray crystallographic analysis (Table 1) showing that the precipitate obtained from the $C D$ solution immediately after evaporation contained 50\% COD, $40 \%$ Bru and $10 \%$ HAP following a volume reduction to $70-$ $80 \mathrm{ml}$, and $35 \%$ COD, $60 \%$ Bru and 5\% HAP when the volume was reduced to $40-50 \mathrm{ml}$. The dominance of CaP, mainly as Bru, was even more pronounced with further volume reduction.

During the 60 minutes following evaporation of the CD-solutions, the crystal number and volume in Sample A did not change (Table 2). In contrast, these variables increased significantly with the more extensive volume reduction in Sample B.

As a result of the presence of seed crystals, a larger number of crystals as well as greater crystal volumes were recorded in the CD-HAP-solutions in comparison with the CD-solutions immediately after evaporation in both Samples A and B (Table 2). As expected, this difference was mainly seen in the size interval of 2.4-5.1 $\mu \mathrm{m}$.

In comparison with the CD-solution, Samples A and
B from the CD-HAP-solutions, had a lower MCV both immediately after evaporation and 60 minutes later (Table 2).

In addition to the added HAP-seed in the CD-HAPsolutions, the larger number of crystals in Samples A and B could probably be explained by the development of $\mathrm{CaOx}$ crystals as shown by X-ray crystallographic analysis of the precipitate. As illustrated in Table 1, a volume reduction to 70-80 $\mathrm{ml}$ and 40-50 $\mathrm{ml}$ increased the $\mathrm{CaOx}$ content in comparison with that recorded in the precipitate retrieved from the CD-solution. Crystals of calcium oxalate monohydrate (COM) were almost entirely found in these samples, whereas, in the absence of HAP crystals, only $\mathrm{COD}$ was found. A more common occurrence of $\mathrm{CaOx}$ crystals in the CD-HAP-solution compared to the CDsolution was also demonstrated with SEM (see, Figs. 2C and 3C).

In Sample B, the number of crystals was about twice as high in the CD-HAPdU-solution as in the CD-HAPsolution, both immediately after evaporation and after 60 minutes ( $\mathrm{p}<0.01$; Table 2). A much smaller and statistically insignificant difference between the two solutions was recorded in sample A. The total stone volume was significantly higher in Sample B from the CD-HAPdU- 
Crystallization in the collecting duct

Table 3. Mean (SD) number and total crystal volume at different sample volumes immediately and 60 minutes after evaporation of $100 \mathrm{ml}$ samples of CD, CD-HAP and CD-HAPdU-solutions

\begin{tabular}{|c|c|c|c|c|c|c|}
\hline \multirow{2}{*}{$\begin{array}{l}\text { crystal siz } \\
\text { interval } \mu \mathrm{r}\end{array}$} & \multicolumn{3}{|c|}{ Sample A (70-95 ml) } & \multicolumn{3}{|c|}{ Sample B (40-69 ml) } \\
\hline & $\mathrm{CD}$ & CD-HAP & CD-HAPdU & $\mathrm{CD}$ & CD-HAP & CD-HAPdU \\
\hline \multicolumn{7}{|c|}{ Number of crystals } \\
\hline \multicolumn{7}{|c|}{2.4 to 5.1} \\
\hline $0 \min$ & $88(92) \dagger \dagger$ & $1279(371)^{\circ}$ & $1328(444)$ & $294(289) \dagger^{\circ}$ & $1670(504)$ & $3592(1755)^{*}$ \\
\hline $60 \mathrm{~min}$ & $94(94)$ & $840(206)^{\circ}$ & $1198(569)$ & $1484(1109)^{\circ}$ & $1833(658)$ & $3979(1359) * *$ \\
\hline \multicolumn{7}{|c|}{5.1 to 10.2} \\
\hline $0 \min$ & $35(32) \dagger$ & $79(19)$ & $142(147)^{\circ}$ & $42(45) \dagger^{\circ}$ & $107(47)^{\circ}$ & $290(126) * * 0$ \\
\hline $60 \mathrm{~min}$ & $24(36)$ & $77(34)$ & $196(190)^{\circ}$ & $340(345)^{\circ}$ & $596(523)^{\circ}$ & $1291(981)^{\circ}$ \\
\hline \multicolumn{7}{|c|}{10.2 to 20.2} \\
\hline $0 \min$ & $7(12)$ & $5(3.2)$ & $8.2(6.0)$ & $11(19)^{\circ}$ & $6.8(5.0)^{\circ}$ & $12.3(1.2)^{\circ}$ \\
\hline $60 \mathrm{~min}$ & $7(13)$ & $7.8(5.5)$ & $20(28)$ & $164(227)^{\circ}$ & $172(288)^{\circ}$ & $125(104)^{\circ}$ \\
\hline \multicolumn{7}{|l|}{$>20.2$} \\
\hline $0 \min$ & $1(1.4)$ & $1(0.7)$ & $0.8(1.0)$ & $0.83(0.9)$ & $0.75(0.9)$ & $0.8(0.8)$ \\
\hline $60 \mathrm{~min}$ & $2(1.3)$ & $0.6(0.6)$ & $0.5(0.9)$ & $85(195)$ & $3.3(5.1)$ & $3(4.0)$ \\
\hline
\end{tabular}

Total crystal volume $\left(1000 \mathrm{x} \mu \mathrm{m}^{3}\right)$

2.4 to 5.1

$\begin{array}{lllllll}0 \min & 2.2(1.7) \dagger \dagger & 22.6(7.8)^{\circ} & 24.8(10.3) & 5.5(4.7) \dagger \dagger^{\circ} & 29.9(9.5) & 70.4(35.9)^{* \circ} \\ 60 \min & 6.1(2.8) \dagger \dagger & 15.9(4.4)^{\circ} & 23.4(12.3) & 31.5(24.6)^{\circ} & 41.6(15.1) & 99.4(47.4)^{\circ}\end{array}$

5.1 to 10.2

$\begin{array}{lllllll}0 \min & 6.6(6.5) & 11.6(3.1) & 21.6(22.9)^{\circ} & 8.2(9.3) \dagger^{\circ} & 17.1(8.4)^{\circ} & 41.7(18.1)^{* * \circ} \\ 60 \min & 6.3(5.8) & 12.3(5.4) & 35.1(37.9)^{\circ} & 69.6(75.1)^{\circ} & 219(330)^{\circ} & 23.0(17.1)^{\circ}\end{array}$

10.2 to 20.2

\begin{tabular}{lcccccc}
$0 \min$ & $8.3(15.2)$ & $6.3(5.1)$ & $9.8(7.3)$ & $12.7(21.9)^{\circ}$ & $7.7(5.4)^{\circ}$ & $14.8(4.1)^{\circ}$ \\
$60 \min$ & $9.6(17.5)$ & $10.2(9.7)$ & $22.1(29.2)$ & $233(336)^{\circ}$ & $189(335)^{\circ}$ & $133(135)^{\circ}$ \\
$>20.2$ & & & & & & \\
$0 \min$ & $17.1(20.7)$ & $13.3(13.8)$ & $5.3(6.0)$ & $4.4(5.5)^{\circ}$ & $11.1(16.8)$ & $6.9(7.8)$ \\
$60 \min$ & $11.3(10.0)$ & $8.5(9.3)$ & $7.9(16.9)$ & $190(377)^{\circ}$ & $23.1(39.3)$ & $20.8(23.5)$ \\
\hline
\end{tabular}

number of experiments

Comparison of CD and CD-HAP samples $\uparrow \mathrm{p}<0.05 ; \uparrow \uparrow \mathrm{p}<0.01$.

Comparison of CD-HAP and CD-HAPdU samples * $\mathrm{p}<0.05$; ** $\mathrm{p}<0.01$.

Comparison of samples immediately and 60 minutes after evaporation ${ }^{\circ} \mathrm{p}<0.05$. 

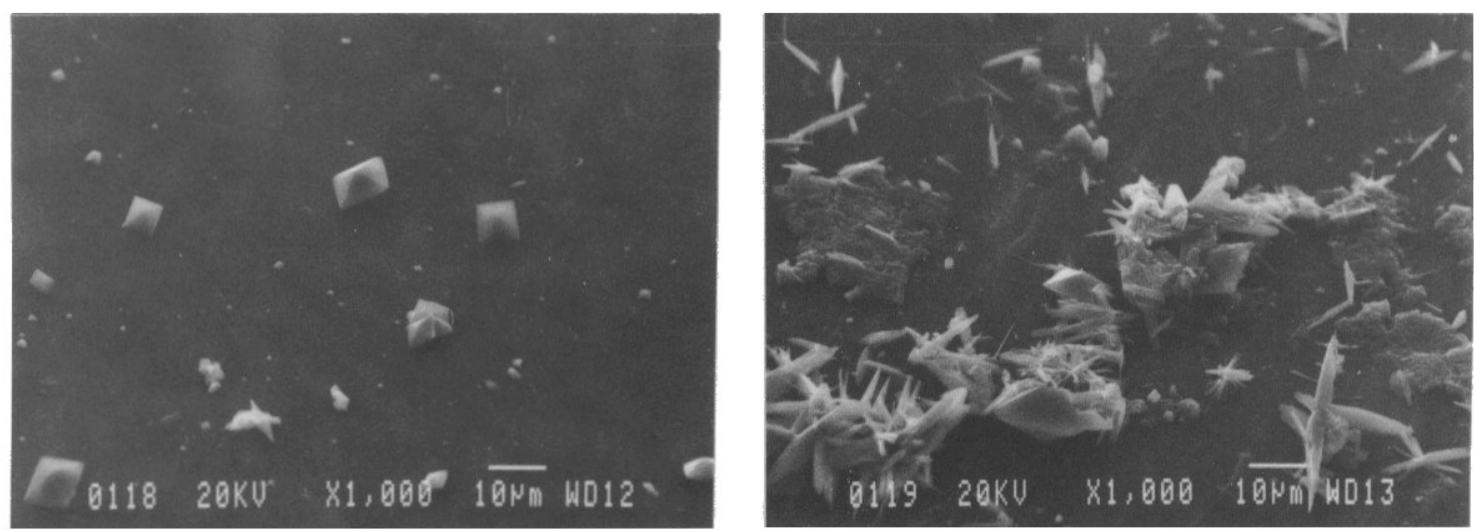

$\mathbf{A}$

B
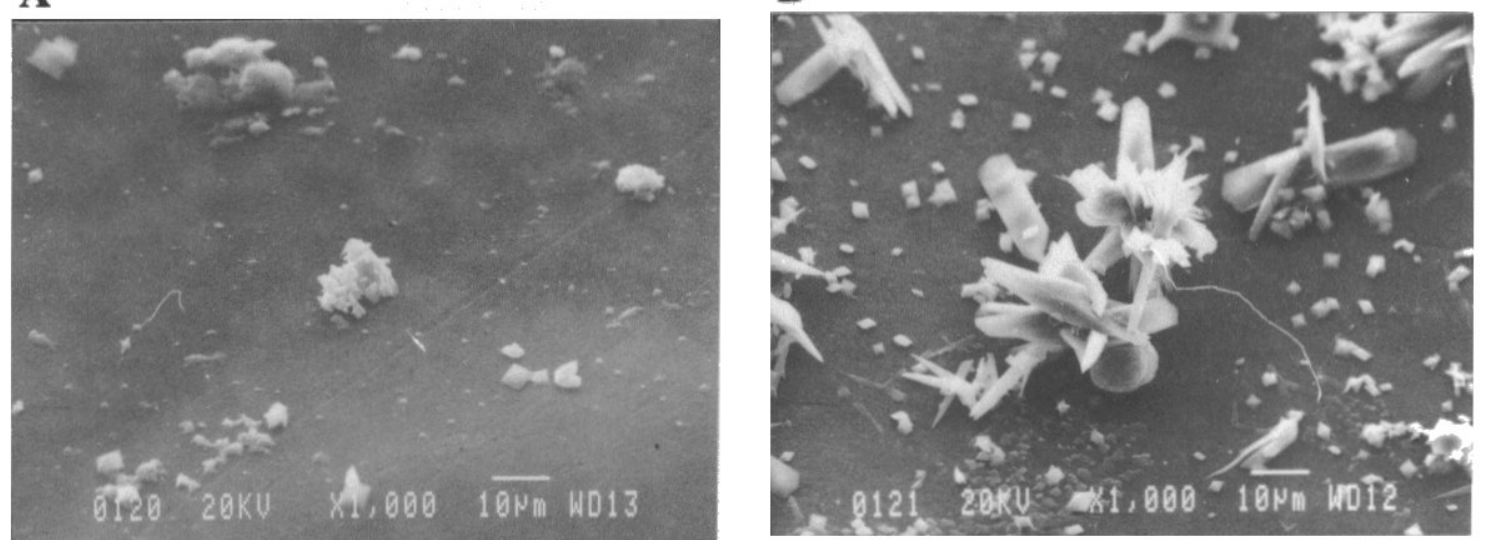

C

D

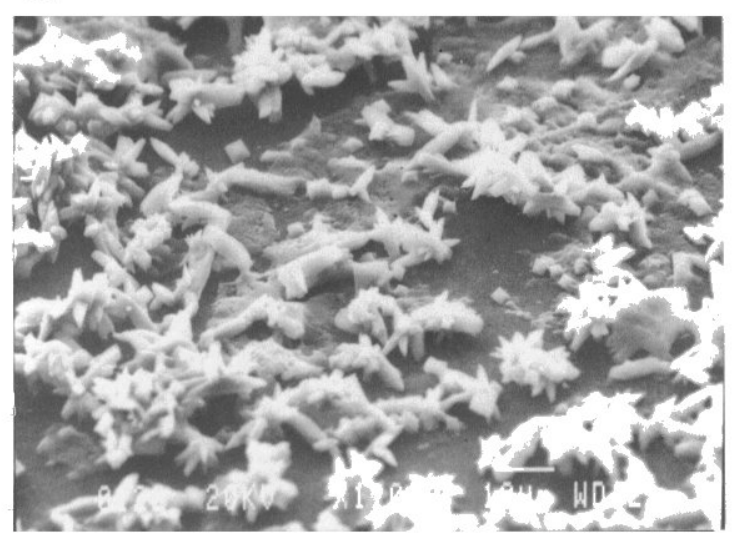

$\mathbf{E}$

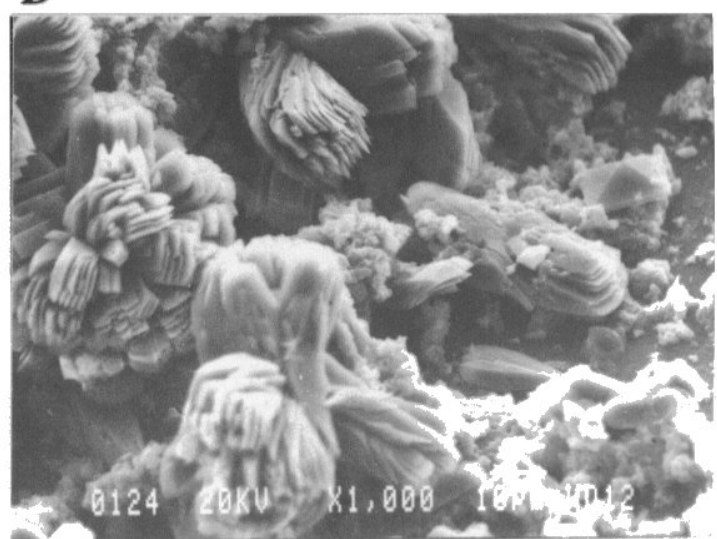

$\mathbf{F}$

Figure 2. Scanning electron micrographs of the precipitate after evaporation of $100 \mathrm{ml}$ samples of CD-solution. (A) and (B) evaporated down to a final volume of 70-80 ml; (C) and (D) evaporated down to a final volume of 40-50 ml; (E) and (F) evaporated down to a final volume of 10-20 ml: (A, C, and $\mathbf{E})$ immediately after evaporation and $(\mathbf{B}, \mathbf{D}$, and $\mathbf{F}) 60$ minutes after evaporation. Bars $=10 \mu \mathrm{m}$. 

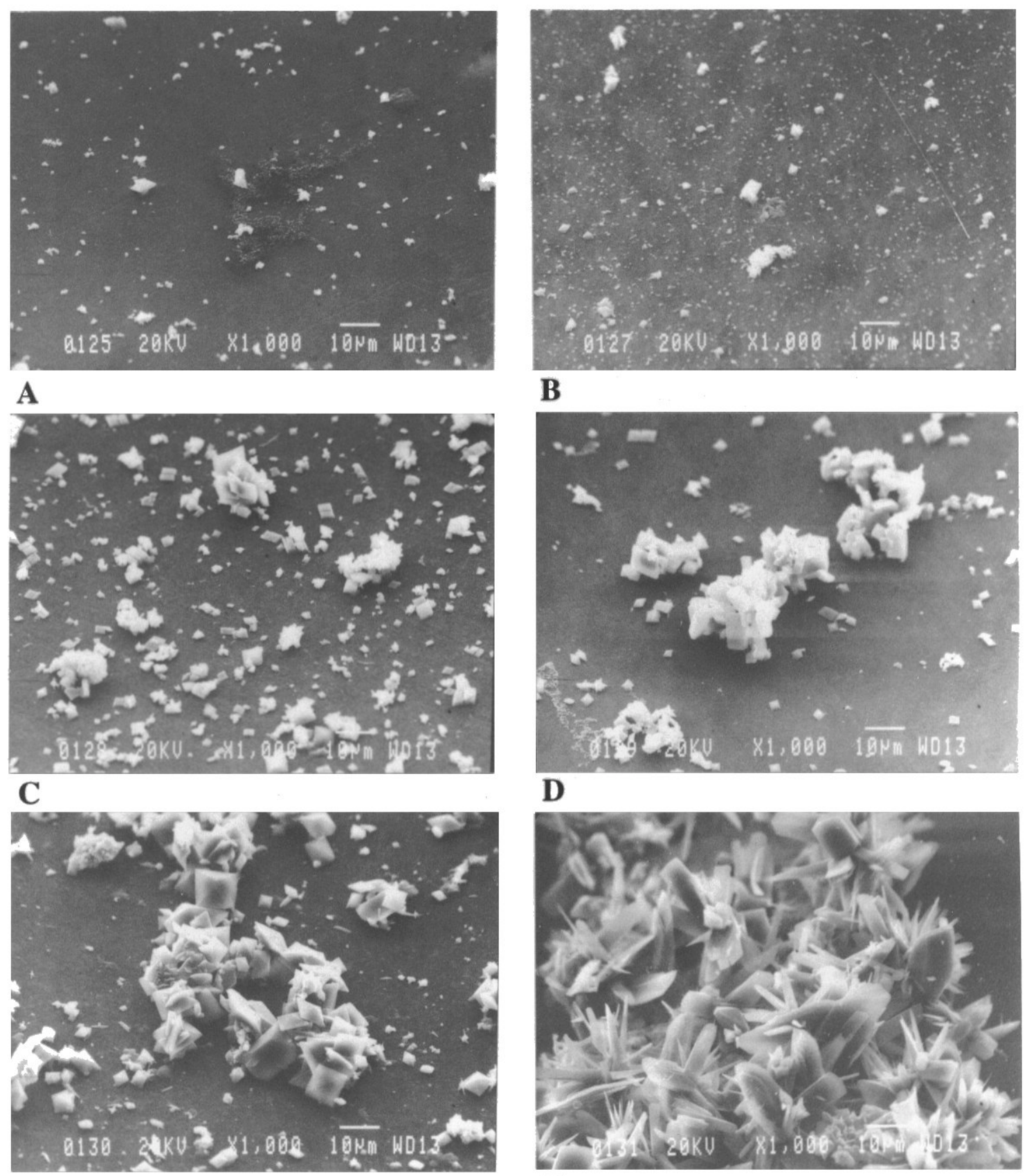

E

\section{D}

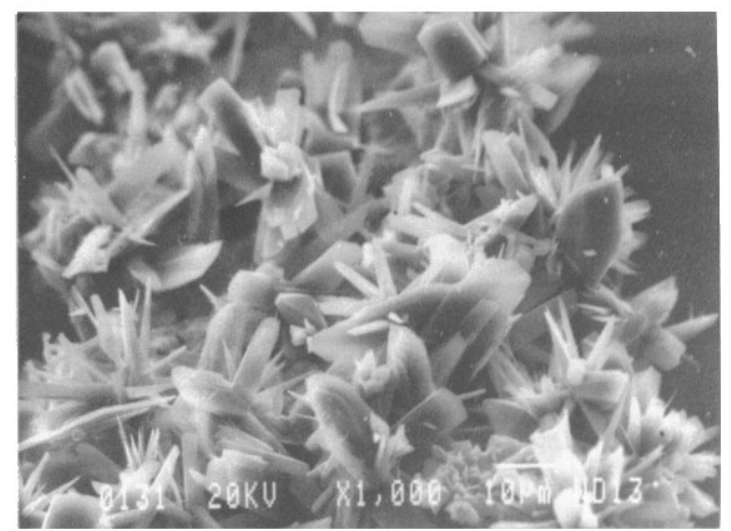

F

Figure 3. Scanning electron micrographs of the precipitate after evaporation of $100 \mathrm{ml}$ samples of CD-HAP-solution. (A) and (B) evaporated down to a final volume of 70-80 ml; (C) and (D) evaporated down to a final volume of 40-50 ml; (E) and (F) evaporated down to a final volume of 10-20 ml: (A, C, and E) immediately after evaporation and (B, D, and F) 60 minutes after evaporation. Bars $=10 \mu \mathrm{m}$. 


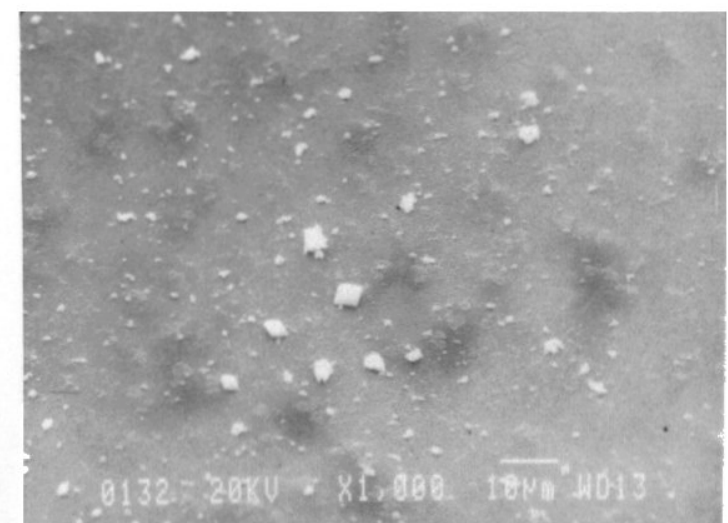

A

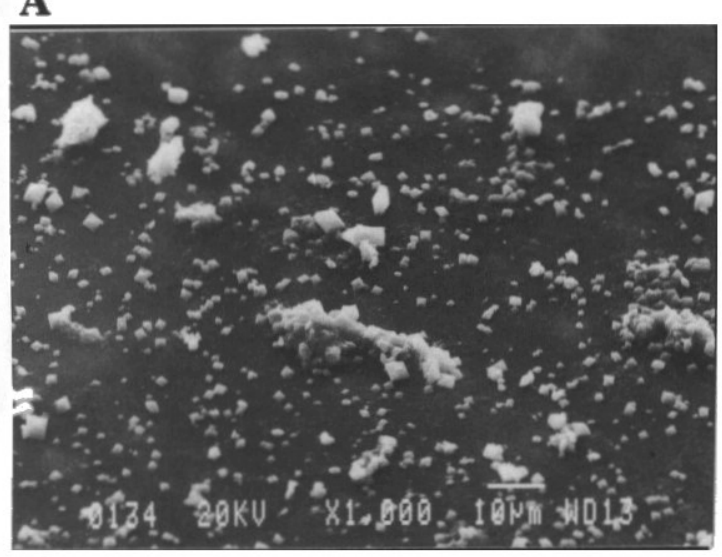

C

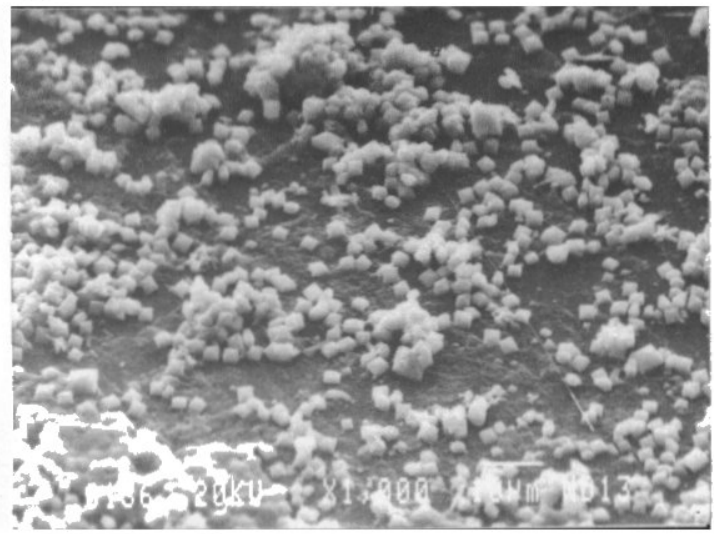

E

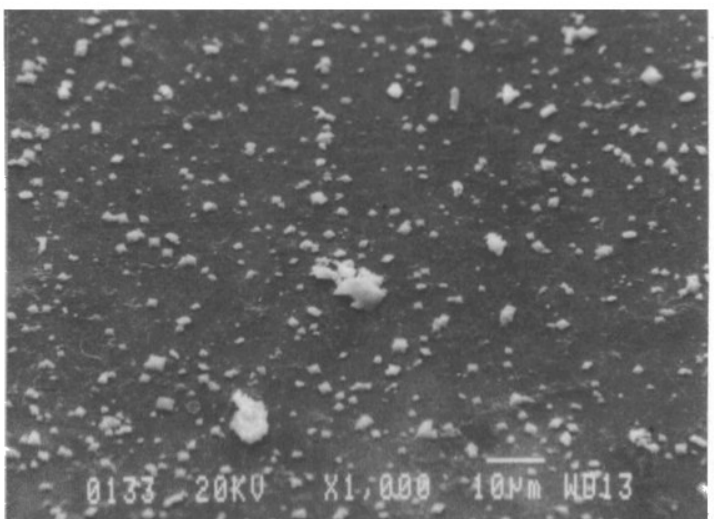

B

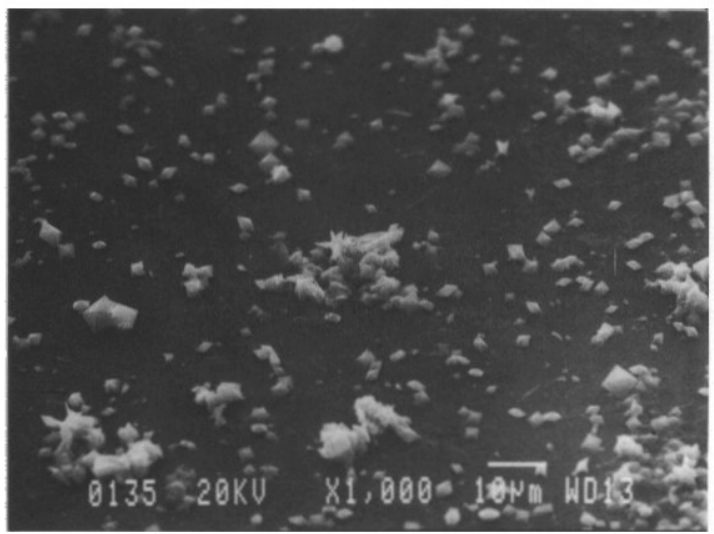

D

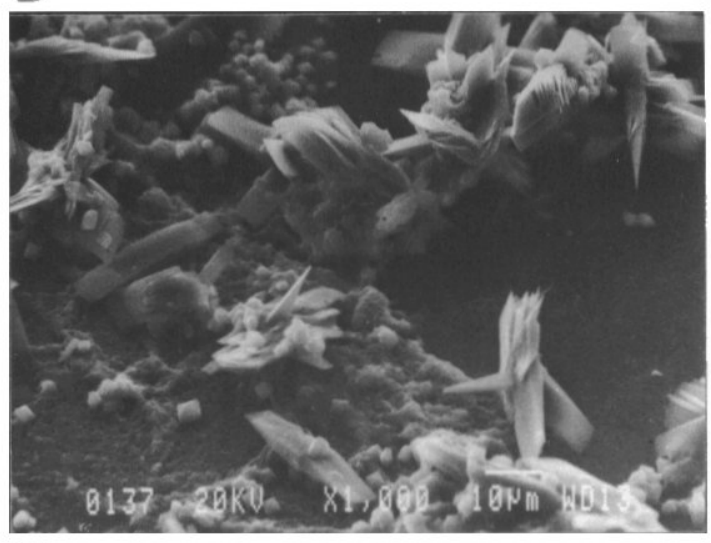

F

Figure 4. Scanning electron micrographs of the precipitate after evaporation of $100 \mathrm{ml}$ samples of CD-HAPdU-solution. (A) and $(\mathbf{B})$ evaporated down to a final volume of $70-80 \mathrm{ml} ;(\mathbf{C})$ and $(\mathbf{D})$ evaporated down to a final volume of $40-50 \mathrm{ml} ;(\mathbf{E})$ and $(\mathbf{F})$ evaporated down to a final volume of 10-20 ml: (A, C, and E) immediately after evaporation, and (B, D, and F) 60 minutes after evaporation. Bars $=10 \mu \mathrm{m}$. 
Table 4. Ion-activity products for $\mathrm{CaOx}$ and different $\mathrm{CaP}$ salts at different volumes after evaporation of $100 \mathrm{ml}$ of the $\mathrm{CD}$ solution.

\begin{tabular}{cccccc}
\hline \hline $\begin{array}{c}\text { volume after } \\
\text { evaporation }(\mathrm{ml})\end{array}$ & $\begin{array}{c}10^{8} \cdot \mathrm{AP}_{\mathrm{CaOx}} \\
(\mathrm{mol} / /)^{2}\end{array}$ & $\begin{array}{c}10^{12} \cdot \mathrm{AP}_{\mathrm{ACP}} \\
(\mathrm{mol} / /)^{2}\end{array}$ & $\begin{array}{c}10^{25} \cdot \mathrm{AP}_{\mathrm{OCP}} \\
(\mathrm{mol} / /)^{8}\end{array}$ & $\begin{array}{c}10^{48} \cdot \mathrm{AP}_{\mathrm{HAP}} \\
(\mathrm{mol} / /)^{9}\end{array}$ & $\begin{array}{c}10^{7} \cdot \mathrm{AP}_{\mathrm{Bru}} \\
(\mathrm{mol} / /)^{2}\end{array}$ \\
\hline 100 & 1.94 & 1.82 & 1.60 & 0.74 & 4.59 \\
90 & 2.18 & 1.83 & 2.03 & 1.56 & 5.32 \\
80 & 2.43 & 1.86 & 2.67 & 3.54 & 6.28 \\
70 & 2.78 & 1.90 & 3.59 & 8.51 & 7.56 \\
60 & 3.20 & 1.98 & 5.08 & 22.5 & 12.1 \\
50 & 3.86 & 2.13 & 7.57 & 65.0 & 16.7 \\
40 & 4.82 & 2.43 & 12.2 & 204 & 25.1 \\
30 & 6.43 & 3.15 & 21.9 & 645 & 45.0 \\
20 & 9.55 & 5.59 & 45.7 & 1454 & 108 \\
10 & 17.1 & 9.36 & 183 & 23000 & \\
\hline \hline
\end{tabular}

solution. These effects could be explained by a larger number of small crystals (Table 3). A significantly lower MCV in the CD-HAPdU-solution was observed in both Samples A and B immediately after evaporation $(\mathrm{p}<0.01)$.

The scanning electron micrographs in Figures 3C, $3 \mathrm{D}, 4 \mathrm{C}$ and $4 \mathrm{D}$ show that the crystals were smaller and apparently less aggregated in the CD-HAPdU-solutions than in the CD-HAP-solutions.

For the most extensively evaporated samples which were reduced to a volume of 10-39 $\mathrm{ml}$, there was no evident difference in terms of number of crystals, crystal volume or MCV compared with the CD-HAP-solution. In the CDHAPdU solution, however, there was a larger number of small crystals than in the CD-HAP-solution. By SEM examination of the precipitate reduced to a volume of 10-20 $\mathrm{ml}$, it was also obvious that the crystals from the CD-HAPdUsolutions were smaller than those from the CD-HAPsolutions (Figs. 3E and 4E), while no important difference was recorded between samples from CD-solutions and CDHAP-solutions (Figs. 2E and 3E).

\section{Ion-activity products}

The ion-activity product of $\mathrm{AP}_{\mathrm{CaOx}}$ exceeded the thermodynamic solubility product for $\mathrm{CaOx}\left(\mathrm{SP}_{\mathrm{CaOx}}\right)$ of 0.23 to $0.25 \times 10^{-8} \mathrm{M}^{2}$ (Pak et al., 1975; Tomazic and Nancollas, 1979) in the samples already before evaporation. A formation product of $\mathrm{CaOx}\left(\mathrm{FP}_{\mathrm{CaOx}}\right)$ around $2 \times 10^{-8} \mathrm{M}^{2}$ was achieved already at a volume reduction to only $90 \mathrm{ml}$ (Table 4). The solutions were supersaturated with respect to $\mathrm{CaP}$, thus, the $\mathrm{AP}_{\mathrm{OCP}}$ and $\mathrm{AP}_{\mathrm{HAP}}$ much exceeded the solubility products of $8.3 \times 10^{-48} \mathrm{M}^{8}$ for $\mathrm{SP}_{\mathrm{OCP}}$ and of $2.35 \times 10^{-59} \mathrm{M}^{9}$ for $\mathrm{SP}_{\text {HAP }}$ (Koutsoukos and Nancollas, 1981) (Table 4). The $\mathrm{AP}_{\text {Вги }}$ exceeded the $\mathrm{SP}_{\text {вги }}$ of $1.87 \times 10^{-7} \mathrm{M}^{2}$ in the nonevaporated solutions but the $\mathrm{FP}_{\text {Вги }}$ of $2 \times 10^{-6} \mathrm{M}^{2}$ (Koutsoukos and Nancollas, 1981; Nancollas, 1982) was reached only after a volume reduction to $30 \mathrm{ml}$. It has to be emphasized, however, that when the ion-activity products were calculated, the decrease in the $\mathrm{pH}$ during volume reduction and complex binding between ions and urinary macromolecules were not accounted for. The ion-activity products, particularly of different calcium phosphate salts might, therefore, be overestimated.

\section{Discussion}

As shown in these experiments, addition of HAP crystals to a $\mathrm{CD}$ solution resulted in deposition of $\mathrm{CaOx}$ already at a volume reduction of only $20-30 \%$. This finding gives support to the hypothesis that $\mathrm{CaP}$ crystals formed at a nephron level above the collecting ducts (Coe and Parks, 1990; DeGanello et al., 1990; Lupták et al., 1994; Kok, 1995; Asplin et al., 1996; Højgaard et al., 1996; Tiselius et al., 1997) might promote the formation of a $\mathrm{CaOx}$ precipitate when these crystals encounter the urine environment in the collecting duct at which level of the nephron both $\mathrm{pH}$ and urine volume are reduced.

Under normal conditions, the $\mathrm{pH}$ will be around 6.75 in the proximal tubule and 6.45 in the distal tubule (Rector, 1983) and it has previously been shown in our laboratory that $\mathrm{CaP}$ is the type of crystal that most easily forms at these levels, whereas $\mathrm{CaOx}$ is the most likely product of crystallization in the collecting duct (Lupták et al., 1994; Højgaard et al., 1996). According to measurements carried out by Asplin et al. (1996), the $\mathrm{pH}$ and the risk of $\mathrm{CaP}$ precipitation might also be high in the loop of Henle. Irrespective of the exact level of CaP precipitation in the nephron, the crystals material will probably move downwards in the nephron. Although small and unretained crystals will be eliminated with urine, this will not be the 
case with crystals that are retained either because of particle size or because of morphological abnormalities in the tubular layer of the collecting duct. Khan (1995), thus, has shown that the crystals easily can get lodged in the distal part of the collecting duct where the channels bend. The interaction between crystals and cells that has been demonstrated by several authors (Khan and Hackett, 1991; Boevé et al., 1993, 1994; Lieske and Toback, 1993; de Bruijn et al., 1994; Verkoelen et al., 1996), might be extremely important for the development of crystals formed in the nephron.

When retained $\mathrm{CaP}$ crystals are exposed to low $\mathrm{pH}$, they might dissolve either partially or completely. Although this dissolution obviously is counteracted by urinary macromolecules (Højgaard et al., 1997, unpublished; Tiselius et al., 1997), it can nevertheless be sufficient to cause a local increment in the supersaturation with $\mathrm{CaOx}$ and hence a CaOx nucleation (Højgaard et al., 1997).

The effect of HAP was studied both in the presence and absence of $\mathrm{dU}$. The presence of macromolecules resulted in a larger number of crystals and a reduced MCV. This is most probably caused by the inhibition of growth and aggregation of the $\mathrm{CaP}$ crystals (Højgaard and Tiselius, unpublished). Urinary macromolecules can also be expected to inhibit the heterogeneous nucleation of $\mathrm{CaOx}$. In comparison with solutions without $\mathrm{dU}$, the content of $\mathrm{CaOx}$ that precipitated following a small volume reduction was lower in solutions with dU. With the higher $\mathrm{CaOx}$ supersaturation following a more extensive evaporation, this difference essentially disappeared. The exact mechanism behind this inhibition has not been elucidated, but it is reasonable to assume that liberated $\mathrm{Ca}^{2+}$-ions bind to $\gamma$ carboxyglutamic acid groups in the macromolecules (Lian et al., 1977; Nishio et al., 1990). Such a binding would, thus, counteract the development of a local critical supersaturation when the solution supersaturation remains low, but not when it becomes high as a result of a pronounced volume reduction.

The increased number of small crystals that appeared following a limited volume reduction of CD-HAP solutions was most certainly the result of $\mathrm{CaOx}$ nucleation on $\mathrm{CaP}$ crystals previously below the detection limit in the Coulter counter. The increased fraction of $\mathrm{CaP}$ associated with extensive volume reductions in the form of brushite was an interesting and unexpected finding. It is reasonable to assume that this is explained by a transformation of HAP to Bru in the acid environment (Abbona and FranchiniAngela, 1990; Lundager-Madsen and Christensson, 1991) and as a result of the increased calcium/magnesium ratio (Abbona and Franchini-Angela, 1990). Obviously, brushite is most easily formed in the absence of both HAP seed and urinary macromolecules. The very high content of brushite, that was recorded following volume reduction to $12-20 \mathrm{ml}$, is unlikely to occur under clinical conditions and probably a volume reduction to $70-80 \mathrm{ml}$ best reflects was happens in stone-formers' urine.

The presence of small HAP seed apparently resulted in a controlled secondary nucleation since both CD-HAP and CD-HAPdU solutions had an MCV smaller than that in the CD-solutions, at least with a size distribution of the kind used in these experiments. A more heterogeneous size distribution with large $\mathrm{CaP}$ crystals or crystal aggregates would, in contrast, provide a basis for the formation of easily retained $\mathrm{CaP} / \mathrm{CaO}$ crystal masses.

In conclusion, we are able to demonstrate that volume reduction of solutions with a composition corresponding to that in the collecting duct resulted in precipitation of $\mathrm{CaOx}$ and that such a process might be augmented by HAP crystals. The precipitation of $\mathrm{CaOx}$ was most obvious when limited volume reduction was carried out, according to that expected under clinical conditions.

\section{Acknowledgements}

We are grateful to Ms. Iréne Ericsson for the assistance with the EQUIL2 calculations, to Mr. Bengt-Arne Fredriksson for always being helpful in the operation of scanning electron microscope. The study was supported by grants from the Linköping Medical Society Foundation and the Åke Wiberg Foundation, Sweden.

\section{References}

Abbona F, Franchini-Angela M (1990) Crystallization of calcium and magnesium phosphates from solutions of low concentration. J Crystal Growth 104: 661-671.

Achilles W, Jöckel U, Schaper A, Ulshöfer B, Riedmiller H (1994) Formation of urinary stones in vitro: Growth of calcium oxalate on spherolites of calcium phosphate in gel. In: Urolithiasis 2. Ryall R, Bais R, Marshall VR, Rofe AM, Smith LH, Walker VR (eds.). Plenum Press, New York. pp. 161-165.

Asplin JR, Mandel NS, Coe FL (1996) Evidence for calcium phosphate supersaturation in the loop of Henle. Am J Physiol 270: F604-F613.

Baumann JM (1985) Invited review: Can the formation of calcium oxalate stones be explained by crystallization processes in urine. Urol Res 13: 267-270.

Baumann JM, Futterlieb A, Lustenberger FX, Wacker M (1984) Crystallization phenomena in human urine after an alimentary oxalate load. In: Pathogenesis and Clinic of Kidneys stones X. Fortschritte der Urologie und Nephrologie, Vol. 22. Vahlensieck W, Gasser E (eds.). Steinkopff, Darmstadt, Germany. pp. 151-155.

Baumann JM, Ackermann D, Affolter B (1989) The influence of hydroxyapatite and pyrophosphate on the 
formation product of calcium oxalate at different $\mathrm{pH}$. Urol Res 17: 153-155.

Berg C, Tiselius HG (1989) The effects of citrate on hydroxyapatite induced calcium oxalate crystallization and on the formation of calcium phosphate crystals. Urol Res 17: $167-172$.

Boevé ER, Ketelaars GAM, Vermeij M, Cao LC, Schröder H, de Bruijn WC (1993) An ultrastructural study of experimentally induced microlith in rat proximal and distal tubules. J Urol 149: 893-899.

Boevé ER, Cao LC, Verkoelen CF, Romijn JC, de Bruijn WC, Schröder H (1994) Glycosaminoglycans and other sulfated polysaccharides in calculogenesis of urinary stones. World J Urol 12: 43-48.

Boyce WH (1956) The amount and nature of the organic matrix in urinary calculi: A review. J Urol 76: 213227.

Coe FL, Parks JH (1990) Defenses of an unstable compromise: Crystallization inhibitors and the kidney's role in mineral regulation. Kidney Int 38: 625-631.

Christoffersen MR, Christoffersen J, Kibalczyc W (1990) Apparent solubilities of two amorphous calcium phosphates and of octacalcium phosphate in the temperature range 30 to $42^{\circ} \mathrm{C}$. J Crystal Growth 106: 349-354.

de Bruijn WC, Boevé ER, van Run PRWA, van Miert PPMC, Romijn JC, Verkoelen CF, Cao LC, Schröder FH(1994) Etiology of experimental calcium oxalate monohydrate nephrolithiasis in rats. Scanning Microsc 8: 541-550.

DeGanello S, Asplin J, Coe FL (1990) Evidence that tubule fluid in the thin segment of the loop of Henle normally is supersaturated and forms a poorly crystallized hydroxyapatite that can initiate renal stones. Kidney Int 37: 472 (abstract).

Finlayson B, Reid F (1978) The expectation of free and fixed particles in urinary stone disease. Investig Urol 15: 442-448.

Grases F, Conte A (1992) Urolithiasis, inhibitors and promoters. Urol Res 20: 86-88.

Hallson PC, Rose GA (1989) Measurement of calcium phosphate crystalluria: Influence of $\mathrm{pH}$ and osmolality and invariable presence of oxalate. Br J Urol 64: 458-462.

Højgaard I, Fornander AM, Nilsson MA, Tiselius HG (1996) Crystallization during volume reduction of solutions with an ion-composition corresponding to that in the distal tubuli. Scanning Microsc 10: 487-498.

Højgaard I, Fornander AM, Nilsson MA, Tiselius HG (1997) The effect of $\mathrm{pH}$ change on the crystallization of calcium salts in solutions with an ion-compositions corresponding to that in the distal tubule. Scanning Microsc 11: this issue.

Hufnagel A, Ottenjann H, Scaper A, Achilles W (1995) Experiments on the formation of artificial urinary stones (1): Effects of spherulites of calcium phosphate on the morphology of stone-like particles. In: Renal Stones: Aspects on Their Formation, Removal and Prevention. Proceedings of the Sixth European Symposium on Urolithiasis. Tiselius HG (ed.). Akademitryck AB, Edsbruk, Sweden. pp. 30-31.

Khan SR (1995) Calcium oxalate crystal interaction with renal tubular epithelium, mechanism of crystal adhesion and its impact on stone development. Urol Res 23: 7179.

Khan SR, Hackett RL (1991) Retention of calcium oxalate crystals in renal tubules. Scanning Microsc 5: 707712.

Kok DJ (1995) Intratubular crystallization events. In: Renal Stones: Aspects on Their Formation, Removal and Prevention. Proceedings of the Sixth European Symposium on Urolithiasis. Tiselius HG (ed.). Akademitryck AB, Edsbruk, Sweden. pp. 26-29.

Kok DJ, Khan SR (1994) Calcium oxalate nephrolithiasis, a free or fixed particle disease. Kidney Int 46: 847854.

Koutsoukos PG, Nancollas GH (1981) Crystal growth of calcium phosphates - epitaxial considerations. J Crystal Growth 53: 10-19.

Larsson L, Öhman S, Sörbo B, Tiselius HG (1984a) Wet chemical analysis of small $(<20 \mathrm{mg}$ ) urinary calculi. In: Urinary Stone. Ryall R, Brochis JG, Marshall V, Finlayson B (eds.). Churchill Livingstone, London, UK. pp. 339-342.

Larsson L, Öhman S, Sörbo B, Tiselius HG (1984b) A method for quantitative analysis of urinary calculi. Clin Chim Acta 140: 9-20.

Leusmann DB, Entrup M, Schmandt W, Blaschke R (1984) Results of the combined phase and texture analyses of 1,028 urinary concrements. Urol Res 12: 94 (abstract).

Lian JB, Prien ELJ, Glimcher MJ, Gallop PM (1977) The presence of protein bound gamma-carboxyglutamic acid in calcium containing renal calculi. J Clin Invest 59: 1151-1157.

Lieske JC, Toback FG (1993) Regulation of renal epithelial cell endocytosis of calcium oxalate monohydrate crystals. Am J Physiol 264: F800-F807.

Lundager-Madsen HE, Christensson F (1991) Precipitation of calcium phosphate at $40^{\circ} \mathrm{C}$ from neutral solution. J Crystal Growth 114: 613-618.

Lupták J, Jensen HB, Fornander AM, Højgaard I, Nilsson MA, Tiselius HG (1994) Crystallization of calcium oxalate and calcium phosphate at supersaturation levels corresponding to those in different parts of the nephron. Scanning Microsc 8: 47-61.

Meyer JL, Bergert JH, Smith LH (1975) Epitaxial relationships in urolithiasis: The calcium oxalate monohydrate-hydroxyapatite system. Clin Sci Mol Med 49: 369374.

Meyer JL, Bergert JH, Smith LH (1977) Epitaxial 
relationships in urolithiasis: The brushite-whewellite system. Clin Sci Mol Med 52: 143-148.

Nancollas GH (1982) Phase transformation during precipitation of calcium salts. In: Biological Mineralization and Demineralization. Nancollas GH (ed.). Springer-Verlag, Berlin, Germany. pp. 79-99.

Nishio S, Kavanagh JP, Fargher EB, Garside J, Blacklock NJ (1990) Calcium oxalate crystallization kinetics and the effects of calcium and gamma-carboxyglutamic acid. Br J Urol 66: 351-356.

Ohkawa M, Tokunaga S, Nakashima T, Yamaguchi K, Orito M, Hisazumi H (1992) Composition of urinary calculi related to urinary tract infection. J Urol 148: 995-997.

Pak CYC (1981) Potential etiologic role of brushite in the formation of calcium (renal) stones. J Crystal Growth 53: 202-208.

Pak CYC, Eanes ED, Ruskin B (1971) Spontaneous precipitation of brushite in urine: Evidence that brushite is the nidus of renal stones originating as calcium phosphate. Proc Natl Acad Sci USA 68: 1456-1460.

Pak CYC, Ohata M and Holt K (1975) Effect of diphosphonate on crystallization of calcium oxalate in vitro. Kidney Int 7: 154-160.

Pak CYC, Hayashi Y, Arnold LH (1976) Heterogenous nucleation with urate, calcium phosphate and calcium oxalate. Proc Soc Exp Biol Med 153: 83-87.

Peacock M, Robertson WG, Marshall RW (1979) Disorders associated with renal calcium-stone disease. Endocrinology 2: 823-837.

Prien L (1955) Studies in urolithiasis III. Physicochemical principles in stone formation and prevention. $\mathbf{J}$ Urol 73: 627-652.

Prien L Sr (1975) The riddle of Randall's plaques. J Urol 114: 500-507.

Rector FC Jr (1983) Acidification of the urine. In: Renal Physiology, Section 8, Handbook of Physiology. Geiger SR, Orloff J, Berliner RW (eds.). American Physiological Society, Washington, DC. pp. 431-454.

Smith LH, Werness PG (1983) Hydroxyapatite - The forgotten crystal in calcium urolithiasis. Trans Am Clin Chem Assoc 95: 183-190.

Swinscow TDV (1976) Statistics at Square One. British Medical Association, London, U.K. pp. 58-61.

Tiselius HG (1984) A simplified estimate of the ionactivity product of calcium phosphate in urine. Eur Urol 10: 191-195.

Tiselius HG (1996) Solution chemistry of supersaturation. In: Kidney Stones: Medical and Surgical Management. Coe FL, Favus MJ, Pak CYC, Parks JM, Preminger GM (eds.). Lippincott-Raven Publishers, Philadelphia, PA. pp. 33-64.

Tiselius HG, Fornander AM, Nilsson MA (1997) Studies on the crystallization process following addition of calcium phosphate crystals to solutions with a composition corresponding to that in the collecting duct. Scanning Microsc 11, (this issue).

Tomazic B, Nancollas GH (1979) The kinetics of dissolution of calcium oxalate hydrates. J Crystal Growth 46: 355-361.

Verkoelen CF, Romijn JC, Cao LC, Boevé ER, de Bruijn WC, Schröder FH (1996) Crystal-cell interaction inhibition by polysaccharides. J Urol 155: 749-752.

Werness PG, Brown CM, Smith LH, Finlayson B (1985) EQUIL2: Basic computer program for the calculation of urinary saturation. J Urol 134: 1242-1244.

\section{Discussion with Reviewers}

B. Hess: What is the authors' explanation for the relatively high percentage of COM crystals in CD-HAP samples, especially after 60 minutes in the sample evaporated to 70$80 \mathrm{ml}$ ?

Authors: We are not able to definitely explain this finding, but it is reasonable to assume that transformation occurs from COD to COM. This process, which is time dependent, might be counteracted by the higher magnesium and citrate concentrations in samples subjected to the most extensive volume reduction.

J.M. Baumann: Ion activity of brushite compared to the activity product of calcium oxalate showed a disproportionately high increase with the increasing volumedepletion by evaporation. Can this phenomena be attributed to the relatively low degree of phosphate chelation (about 5\%) compared to the much higher degree of oxalate chelation (about 30\%) and can it explain the predominance of brushite precipitation in the highly concentrated samples? Authors: In these solutions, differences in the free concentrations of $\mathrm{HPO}_{4}^{2-}$ and $\mathrm{Ox}^{2-}$, respectively, are highly important for whether $\mathrm{CaOx}$ or $\mathrm{CaHPO}_{4}$ will be the favored product of precipitation. At the $\mathrm{pH}$ used, volume reduction caused an increase in $\mathrm{HPO}_{4}^{2-}$ that was more pronounced than for $\mathrm{Ox}^{2-}$, a fact that might have been of great importance for brushite precipitation.

J.M. Baumann: Blocking growth sites on crystals and crystal nidus is a generally accepted mechanism to explain the effect of crystallization inhibitors. The authors support the interesting theory that calcium phosphate formed in renal tubules may dissolve in the $\mathrm{CD}$ due to a lower $\mathrm{pH}$, produce local zones of high calcium concentration or calcium oxalate supersaturation, respectively, and thus, induce calcium oxalate nucleation. Macromolecular inhibitors are thought to bind calcium ions liberated by calcium phosphate dissolution and, thus, counteract nucleation of calcium oxalate. However, we wonder how the authors can explain 
this effect knowing that calcium concentrations are in the millimolar range, whereas, macromolecular inhibitors, like Tamm Horsfall protein (THP), are only present in nanomolar concentrations. THP has a molecular weight of about 80 $\mathrm{KD}$ and is excreted in amounts of 40 to $50 \mathrm{mg}$ per day.

Authors: The exact role of macromolecules in this respect is abstrusive. Macromolecules will certainly bind $\mathrm{Ca}^{+}$-ions to numerous specific binding sites. This complex formation can slightly affect the ion-activity products of $\mathrm{CaOx}$ as well as $\mathrm{CaP}$, but the inhibition of $\mathrm{CaOx}$ crystal growth is counteracted by binding of macromolecules to the crystal surface. When $\mathrm{CaP}$ crystals occur in solutions containing macromolecules, they dissolve more slowly than without macromolecules. This is probably an effect of a slow diffusion of ions through the macromolecular layer surrounding the crystals. The establishment of a high concentration at these sites might induce nucleation, but, when the $\mathrm{CaOx}$ crystals have formed, normal macromolecules will protect them from growing. The macromolecules, thus, might act through the accumulation of $\mathrm{Ca}^{2+}$-ions by forming areas with high levels of supersaturation and by providing a gel environment that facilitates nucleation but counteracts dissolution. In such a system, it is difficult to draw conclusions from purely stoichiometrical calculations.

J.M. Baumann: A further question is how the authors, by their theory, explain the finding of an increased crystal number and a decreased mean crystal volume in dU?

Authors: The increased crystal number and decreased mean crystal volume in the presence of dU might be an effect of aggregation inhibition brought about by the macromolecules.

J.M. Baumann: In most experiments, heterogeneous nucleation has been studied in solutions being saturated with respect to the nucleator (e.g., HAP), where neither a dilution nor a precipitation of the nucleator occurs. Obviously, the authors tried to simulate conditions as found in the CD also with respect to phosphate. Why did they omit uric acid?

Authors: Our aim was to make observations of $\mathrm{CaOx}$ and $\mathrm{CaP}$ precipitation in solutions that were supersaturated with these salts to approximately the same extent as tubular urine. Urate has a small influence on the ion-activity products of both $\mathrm{CaOx}$ and $\mathrm{CaP}$, but this effect is only marginal. It is also possible, however, that urate promotes precipitation of $\mathrm{CaOx}$. This has been a matter of debate for more than a decade. During the volume reduction, sodium urate as well as uric acid might, under certain circumstances, precipitate and although this might be of great importance for the crystallization, we thought that the presence of urate would make conclusions more difficult as our intention was to study what happened to $\mathrm{CaOx}$ and $\mathrm{CaP}$. Urate, therefore, was excluded on the same grounds as ammonium: to assure a pure calcium salt precipitation. This does not mean that we consider urate unimportant and future studies of the crystallization in solutions with and without urate might shed light on the role of urate in the calcium crystallization process.

L.-C. Cao: Why did the authors select to measure crystal nucleation in the size range $2.4-45 \mu \mathrm{m}$ when a considerable proportion might be found between 2 and $2.4 \mu \mathrm{m}$ ?

Authors: To assess the nucleation is indeed an extremely difficult task and ideally, a method should be used, which allows detection of particles as small as 1-2 $\mathrm{nm}$. Besides the lack of technical equipment for such measurements, most solutions contain impurities giving a considerable background noise, which increases with decreasing size of the particles we want to measure. Although, the Coulter counter with a $100 \mu \mathrm{m}$ tube allows for particle size analysis down to $2 \mu \mathrm{m}$, we found that the reproducibility for this type of experiments was much better with the threshold set at $2.4 \mu \mathrm{m}$.

F. Grases: Do you think that, in any case, the crystals formed in the distal tubules can obstruct them, and, if this would occur, what type of renal calculi would be formed?

Authors: Whether crystals formed in the tubular system might be sufficiently large to obstruct them is a matter of debate. In case of $\mathrm{CaP}$ nucleation in the distal part of the distal tubule, we believe that the risk of tubular obstruction is negligible. The crystals might, however, be retained at this level and, as long as they remain there, $\mathrm{CaP}$ will be the type of crystals encountered.

F. Grases: If crystals formed in the distal tubules are not retained there or within the collecting ducts, can they induce renal calculus formation? Why and where?

Authors: In our hypothetical model, the initial $\mathrm{CaP}$ precipitate induces $\mathrm{CaOx}$ precipitation in the lower part of the collecting duct, where adherence to the tubular cells might cause retention and further crystal growth. The final steps in this process are less well understood, but the experimental results reported by Khan (1995, Additional References) have shown an important interaction between the crystal material and the tissues at that level.

L.-C. Cao: Regarding your theory of intratubular crystallization, do you have any ideas on how to improve the treatment of patients with stone disease?

Authors: From a therapeutic point of view, it would be desirable to prevent $\mathrm{CaP}$ crystallization in the nephron. A reduced excretion of calcium and a strict control of intratubular $\mathrm{pH}$ might be of crucial importance to achieve this goal. Correction of an abnormally low citrate excretion, thus, has to be undertaken with the risk of intratubular $\mathrm{CaP}$ 
crystallization in mind. We cannot say, however, whether an excessive alkalinization increases the risk of stone formation or not. The reason for this is that whereas $\mathrm{CaP}$ more easily forms at high levels of the nephron, the dissolution at CD-levels is counteracted. Further experimental and clinical studies will be necessary to answer this question.

L.-C. Cao: Will 24-hour urinary parameters be useless for evaluating metabolic disorders in a given stone patient?

Authors: The usefulness of 24-hour urine samples or any samples collected during periods of various duration for evaluation of the risk of stone-formation is an interesting and important issue to consider. Whatever the urine composition might be at the nephron level where we assume that the initial steps of the crystallization take place, this might at least, to some extent, be reflected in the composition of final urine. Recent calculations of the ion-activity product of $\mathrm{CaP}$ in the distal part of the distal tubule, by extrapolation from 16-hour urine, indicated a good relationship between $\mathrm{AP}_{\mathrm{CaP}}$ index in voided urine and $\mathrm{AP}_{\mathrm{CaP}}$ in tubular urine (Tiselius et al., 1997, Additional References). In addition, final urine more closely reflects the composition below the $\mathrm{CD}$-level where $\mathrm{CaOx}$ crystallization predominates. In our view, urine collections, thus, give valuable information on the risk situation in the renal collecting system, but the interpretation has to made in view of the variations in urine composition that occur when urine passes through the nephron.

\section{Additional References}

Khan SR (1995) Experimental calcium oxalate nephrolithiasis and the formation of human urinary stones. Scanning Microsc 9: 89-101.

Tiselius HG, Fornander AM, Nilsson MA. (1997) Estimated levels of supersaturation with calcium phosphate and calcium oxalate in the distal tubule. Urol Res, 25: 153-159. 